КРАТКИЕ СООБЩЕНИЯ

УДК 552.51:551.763.12(470.324)

DOI: https://doi.org/10.17308/geology.2020.3/3012

ISSN 1609-0691

Поступила в редакцию: 28.08.2020

Принята к публикации: 02.09.2020

Опубликована онлайн: 30.09 .2020

\title{
Новые источники минералов титана и циркония из песков аптского яруса по материалам работ ГДП-200
}

\author{
(C2020 А. В. Крайнов ${ }^{1 \bowtie}$, А. Е. Звонарев ${ }^{2}$ \\ ${ }^{1}$ Воронежский государственный университет, \\ Университетская пл. 1, 394018, Воронеж, Российская федерация \\ ${ }^{2}$ ООО «Медногорский медно-серный комбинат», Воронеж, Российская Федерация
}

\begin{abstract}
Аннотация
Введение: На территории Центрально-Черноземного района (ЦЧР) россыпи титана и циркония являются ценным и одновременно дефицитным сырьем. Повышенные содержания минералов титана и циркония отмечены в песчаных отложениях почти всех стратиграфических подразделений геологического разреза, но перспективными на обнаружение их россыпей в пределах ЦЧР являются: песчано-глинистые отложения верхнего девона (коми надгоризонт), барремского, аптского, альбского ярусов нижнего мела, сеноманского яруса верхнего мела и неогена. Несмотря на наличие поставленных на баланс россыпей, таких как Центральная (сеноманский ярус верхнего мела), отработка их как самостоятельных полезных ископаемых остается нерентабельной. Поэтому стоит вопрос о попутном извлечении минералов титана и циркония при добыче строительных, стекольных и формовочных песков. Этот вопрос решался при проведении работ ГДП-200.

Методика: Решение поставленных задач определило использование комплекса методик. Были проведены полевые исследования, камеральные построения фациальных карт и разрезов, лабораторные и технологические испытания. На основании комплексного анализа полученных данных выделены таксоны для регионального минерагенического районирования в рангах: минерагенические (рудные) зоны (Р3), районы (РР) и узлы (РУ). В процессе проведения работ задокументирован и опробован керн более 50 скважин, описаны и опробованы породы свыше 100 точек наблюдений (обнажения и карьеры) в пределах Воронежской, Курской, Липецкой, Орловской областей. Подготовлены пробы, с помощью прецизионных методов изучен минеральный и химический составы песчаных отложений около 100 образцов.

Результаты и обсуждение: Перспективные на стекольное сырье пески аптского яруса были обследованы на предмет содержания в них минералов тяжелой фракции. Тяжелая фракция представлена цирконом, лейкоксеном, ильменитовой ассоциацией с незначительным содержанием дистена, рутила, ставролита и турмалина. Формирование россыпей происходило за счет перемыва и шлихования алевро-песчаного материала в континентальных и прибрежно-морских обстановках. Многократные перемывы и шлихование песков - одно из главных условий накопления минералов тяжелой фракции. Титан-циркониевые россыпи относятся к россыпям дальнего переноса. Источниками сноса для них служили более зрелые палеозой-мезозойские осадочные породы Воронежской антеклизы.

Bblвoдbl: В результате работ ГДП-200 впервые выделены и поставлены на учет рудные узлы, для которых посчитаны прогнозные ресурсы категории $\mathrm{P}_{3}$ для титана, циркония и стекольных песков. Ключевые слова: пески, циркон-титановое сырье, ГДП-200.
\end{abstract}

Контент доступен под лицензией Creative Commons Attribution 4.0 License.

\footnotetext{
Крайнов Алексей Владимирович, e-mail: aleksey_vsu_geo@mail.ru
} 
Для циттирования: Крайнов А. В., Звонарев А. Е. Новые источники минералов титана и циркония из песков аптского яруса по материалам работ ГДП-200 // Becmник Воронежского государственного университета. Серия: Геология. 2020. №3. С. 90-95. DOI: https://doi.org/10.17308/geology.2020.3/3012

\section{Введение}

В последние годы на фоне истощения минеральносырьевой базы в России россыпного титана и циркония и в рамках решения вопроса импортозамещения, большое внимание привлекается к проблеме поиска альтернативных источников данного стратегического сырья. В качестве таковых часто рассматриваются пески различных стратиграфических уровней, используемых в качестве строительных материалов $[1,2]$. Осуществляются попытки по разработке технологий извлечения высоколиквидного сырья при переработке строительных песков. В связи с этим актуальна оценка отдельных участков, перспективных на выявление кварцевых песков, содержащих повышенные количества минералов титана и циркония.

Предшествующими работами по созданию Государственной геологической карты листов М-37 (Воронеж) и N-37 (Москва) в пределах первого листа выделена Павловско-Обоянская титан-циркониевая минерагеническая зона, которая приурочена к широкому спектру отложений: от верхнего девона до миоцена. Она протягивается полосой с юго-востока на северо-запад от Богучара через Россошь, Павловск, Алексеевку, Острогожск, Белгород, Обоянь. Внутри зоны выделено два рудных района - Обоянский (4 рудных узла, приуроченных к полтавскому надгоризонту) и Павловский (3 рудных узла, приуроченных к коми надгоризонту). Для рудных узлов подсчитаны прогнозные ресурсы по категориям $\mathrm{P}_{1}$ и $\mathrm{P}_{2}$. Суммарные прогнозные ресурсы составляют для $\mathrm{TiO}_{2} 21.3$ млн т, для $\mathrm{ZrO}_{2}-6.1$ млн т.

Выделенная в пределах листа N-37 (Москва) Плавск-Скопин-Липецк-Елецкая зона охватывает площадь развития песчано-глинистой валанжин-аптской осадочной формации. Зона объединяет Липецкий (3 рудных узла и 1 рудное поле) и прогнозируемый Елецко-Ливенский россыпные районы, выделенные Н. Н. Иконниковым в 1983 г. [3]. Она проходит полумесяцем от г. Елец, далее через Липецк, Лев Толстой, Данков, Скопин, Новомосковск. Суммарные прогнозные ресурсы по категориям $\mathrm{P}_{1}+\mathrm{P}_{2}$ для Липецкого РУ составляют 4.4 млн т, для Елецко-Ливенского $-\mathrm{P}_{3}-2.35$ млн т.

В рамках проведения геологического доизучения площадей масштаба 1:200 000 листов M-37-III (Касторное), N-37-XXXIII (Елец) были выявлены рудные узлы, в пределах которых распространены породы аптского яруса нижнего отдела меловой системы.

\section{Методика}

Одной из задач ГДП-200 является «локализация перспективных площадей, оценка прогнозных ресур- сов категории $\mathrm{P}_{3}$ титан-циркониевых россыпей, подготовка рекомендаций по постановке поисковых работ на локализованных перспективных участках с паспортами учета перспективных объектов». Выделение перспективных участков основывается на анализе рудоконтролирующих факторов и поисковых признаков полезных ископаемых. Среди основных факторов, определяющих становление месторождений в осадочном чехле Воронежской антеклизы, выделяются общие, создающие предпосылки для их формирования и частные, определяющие вид гипергенных полезных ископаемых. В первую группу входят тектонический, климатический, стратиграфический и эволюционный факторы. Ко второй группе отнесены палеогеоморфологический, литологический, гидродинамический, органический, диагенетический, эпигенетический, вулканогенный и гидротермальный [4]. Подробная методика минерагенических построений [5] описана в работе [6].

\section{Обсуждение результатов}

Аптский ярус указанного района в объеме латненского горизонта представлен криушанской, девицкой и волчинской свитами [7].

Криушанская свита представляет собой русловой аллювий [8], сложенный песками с тонкими прослоями глин. Пески, как правило, разнозернистые, с преобладанием средне- и мелкозернистых, плохо сортированных, кварцевые, с прослоями более грубозернистых, в различной степени глинистые и алевритистые. Для них характерна хорошо выраженная косая разнонаправленная слоистость, состоящая из серии косослоистых ритмов, разделенных прослоями с горизонтальной слоистостью. Мощность свиты очень непостоянна, составляет от 2 до 16 м.

Девицкая свита согласно залегает на криушанской, имеет широкое распространение, представлена пойменно-старичными глинистыми фациями глины, пески, алевриты.

Глины залегают в виде крупных линз, не выдержанных по мощности, часто фациально замещаются песками и алевритами. Пески тонко- мелкозернистые, хорошо сортированные, кварцевые, преимущественно глинистые. Алевриты светло-серые и серые, иногда со слабым зеленоватым оттенком, плотные, глинистые. В них отмечаются прослои и линзы серой плотной глины. Мощность свиты очень непостоянна и колеблется от 1 до 19 м.

Волчинская свита согласно залегает на девицкой, не имеет сплошного распространения и представлена мелко-тонкозернистыми, хорошо сортированными, кварцевыми пастиловидными тонко-горизонтальнослоистыми песками с мелко-тонкозернистыми, хорошо сортированными, кварцевыми песчаниками в средней части. Мощность свиты до 7 м. Работами по ГДП-200 выявлен ряд минерагенических узлов развития стекольных песков (рис. 1), которые описаны в работе [9]. 


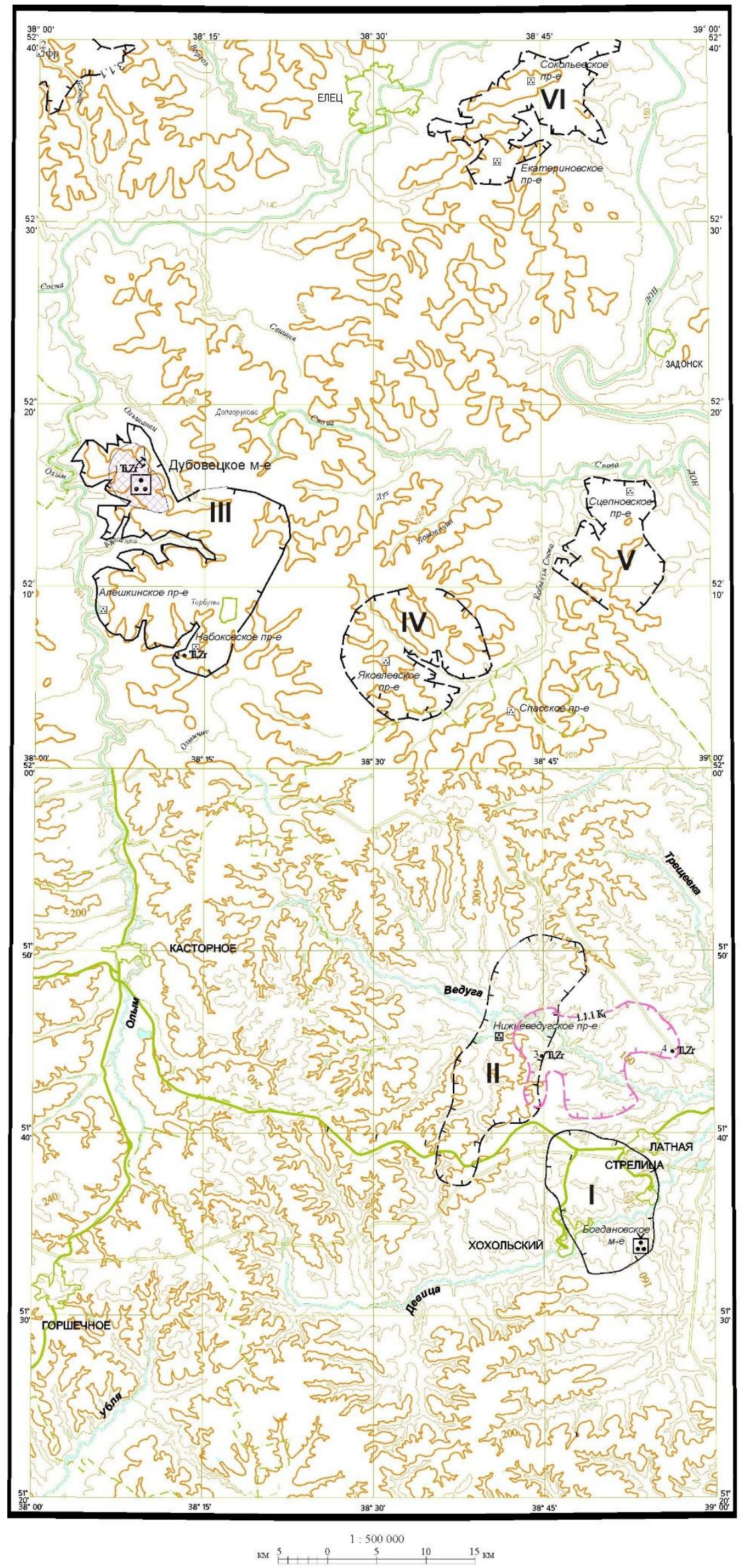

Рис. 1. Схема минерагенического районирования стекольных песков и россыпей титана и циркония, выявленных при ГДП-200 листов М-37-III (Касторное) и N-37-XXXIII (Елец): I - Стрелицкий рудный узел (РУ), II прогнозируемый Нижневедугский РУ, $I I I$ - Дубовецкий РУ, $I V$ - потенциальный Яковлевский РУ, $V$ - потенциальный Алексеевский РУ, VI - потенциальный Елецкий РУ; пункты минерализации Тi и Zr: 1 - Дубовецкий россыпь; 2 - Голубевский; 3 - Стрелицкий; 4 Девицкий.

[Fig. 1. Scheme of mineragenic zoning of glass sands and placers of titanium and zirconium, revealed during the GDP-200 sheets M-37-III (Kastornoye) and N-37-XXXIII (Yelets): I - Strelitskiy ore cluster, $I I$ - predicted Nizhne Vedugskiy ore cluster, III - Dubovetskiy ore cluster, $I V$ - potential Yakovlevskiy ore cluster, $V$ - potential Alekseevskiy ore cluster, $V I$ - potential Eletskiy ore cluster; points of $\mathrm{Ti}$ and $\mathrm{Zr}$ mineralization: 1 Dubovetsky placer; 2 - Golubevsky; 3 Strelitsky; 4 -Devitsky.] 
Анализ этих песков с целью выявления повышенных содержаний тяжелой фракции на основании полученных и фондовых сведений позволил установить четыре пункта минерализации: (Дубовецкий (1), Голубевский (2), Стрелицкий (3) и Девицкий (4)), приуроченных к криушанской и девицкой свитам (см. рис. 1).

Совмещение прогнозной карты с современной литолого-фациальной картой аптского века позволяет установить приуроченность пунктов минерализации к пескам, накапливавшимся в пристрежневых условиях за счет перемыва и шлихования алевро-песчаного материала. Выход тяжелой фракции составляет до

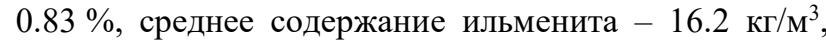

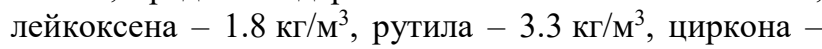
$3.0 \kappa \Gamma / \mathrm{M}^{3}$.

На примере выявленных пунктов минерализации отмечаются некоторые общие закономерности изменения гранулометрических и минералогических характеристик в разрезе криушанской и девицкой свит. Для песков аптского яруса в целом, при некоторых вариациях по разрезу, характерно преобладание мелкоразмерной фракции 0.1-0.25 мм до 70\%, а в сумме с фракцией 0.25-0.5 мм до 90\%. К основанию слоя увеличивается доля крупнозернистых фракций с преобладанием средней и мелкой размерности 36.4 и $28.4 \%$ соответственно. В том же направлении растет содержание и тяжелой фракции от 0.43 до $0.56 \%$.

Распределение тяжелой фракции в песках разреза неравномерно. Для мелкозернистых песков толщи характерны содержания около $0.16 \%$, не значительны они и для подошвы разреза, где в грубо-крупнозернистых несортированных разновидностях составляют $0.26 \%$, наибольшие значения характерны для средней части разреза $0.36-0.56 \%$.

Статистические параметры песков, обогащенных титан-циркониевым сырьем, вынесенные на динамогенетическую диаграмму Г. Ф. Рожкова и генетическую диаграмму К. К. Гостинцева указывают на постоянные изменения условий накопления осадков от русловых до пойменных. Отмечается увеличение тяжелой фракции в песках, которые на данных диаграммах соответствуют полю континентальной микрофации пляжей больших равнинных рек или пойм соответственно.

Тяжелые минералы концентрируются в размерном классе 0.5-0.01 мм с максимальным содержанием до $75 \%$ во фракции $0.25-0.1$ мм и $30 \%$ в $0.1-0.063$ мм, для пастиловидных песков характерно повышение значений до 48\%, и в классе 0.063-0.045 мм до 16\%.

Тяжелая фракция представлена циркон (10-24\%) лейкоксен (12-50\%) - ильменитовой ассоциацией (29$65 \%)$ с незначительным содержанием дистена (2-5\%), рутила (2-3\%), ставролита (1-2\%) и турмалина (1-3\%), прочие минералы встречены в единичных знаках. В целом содержание полезных минералов (ильменит, рутил, лейкоксен, циркон) составляет 91-96\%.
Таким образом, выделены два титан-циркониевых рудных узла 1 - Дубовецкий, который территориально совпадает с одноименным РУ стекольных песков и 2 Кондрашевский, расположенный на западе листа М37-III. Для этих рудных узлов подсчитаны прогнозные ресурсы по категории $\mathrm{P}_{3}$. Суммарные прогнозные ресурсы по двум РУ составляют для $\mathrm{TiO}_{2}-5.1$ млн т и для $\mathrm{ZrO}_{2}-844$ тыс. т. Поисковые работы рекомендовано проводить вблизи проявлений стекольных песков с обязательной оценкой на титан и цирконий.

\section{Заключение}

Проведенные работы позволили выделить перспективные площади на пески для комплексной отработки с титан-циркониевым сырьем. Особое значение имеют пески средней части криушанской и девицкой свит, которые после обогащения (гидроклассификация, электромагнитная сепарация) можно использовать, не только как строительные и более высоких категорий (стекольные и формовочные), но и как источник циркон-титанового концентрата.

Конфликт интересов. Авторы декларируют отсутствие явных и потенциальных конфликтов интересов, связанных с публикацией настоящей статьи.

\section{ЛИТЕРАТУРА}

1. Звонарев А. Е. О новом источнике титан-циркониевого сырья Центрального Черноземья // Комплексное изучение и освоение природных и техногенных россыпей: тез. докл. 4 междунар. науч.-практ. конф., г. Симферополь - Судак, Симферополь, 2007. С. 42-43.

2. Савко А. Д., Михин В. П., Холмовой Г. В Литология и полезные ископаемые аптских отложений междуречья Дон-Ведуга. Труды научно-исследовательского института геологии: Воронеж, Изд-во Воронеж. гос. ун-та. Вып. 26. 2004. 111 с.

3. Савко А. Д., Беляев В. И., Иконников Н. Н., Иванов Д. А. Титан-циркониевые россыпи Центрально-чернозёмного района. Воронеж, 1995. 148 с.

4. Савко А. Д. Историческая геология: учебное пособие. Воронеж: Воронежский государственный университет, 2006. $450 \mathrm{c}$.

5. Металлогенический кодекс России. Москва, ГеокартГЕОС, 2012. 125 c.

6. Крайнов А. В., Мануковский С. В. Минерагеническое районирование керамических глин Воронежской антеклизы // Вестник Воронежского государственного университета. Серия: Геология. 2020. № 1. С. 66-77.

7. Савко А. Д. Геология Воронежской антеклизы. Труды научно-исследовательского института геологии: Воронеж, Изд-во Воронеж. гос. ун-та. Вып. 12. 2002. 165 с.

8. Савко А. Д., Мануковский С. В., Мизин А. И., Бурыкин В. Н., Бартенев В. К. Объяснительная записка к атласу фациальных карт Воронежской антеклизы. Труды научно-исследовательского института геологии: Воронеж, Изд-во Воронеж. гос. ун-та. Вып. 20. 2004. 107 с.

9. Крайнов А. В., Горюшкин В. В. Минерально-сырьевая база стекольных песков Центрально-Черноземного района и перспективы ее развития // Вестник Воронежского государственного университета. Серия: Геология. 2017. № 1. С. 90-95. 
UDC 552.51:551.763.12(470.324)

DOI: https://doi.org/10.17308/geology.2020.3/3012

Received: 28.08 .2020

Accepted: 02.09.2020

Published online: 30.09 .2020

\title{
New sources of titanium and zirconium minerals from the sand of the Aptian stage based on materials obtained during the 1:200,000 additional site exploration
}

\author{
CO2020 A. V. Kraynov ${ }^{凶}$, A. E. Zvonarev \\ Voronezh State University, 1 Universitetskaya pl., Voronezh 394018, Russian Federation
}

\begin{abstract}
Introduction: In the territory of the Central Black Earth Region, titanium and zirconium placers are valuable and at the same time scarce raw materials. The high content rates of these minerals are noted in the sandy deposits of almost all stratigraphic subdivisions of the geological section. However, the most promising deposits in the Central Black Earth Region where titanium and zirconium placers may be found are the following: sand and clay deposits of the Upper Devonian (Komi superhorizon), Barremian, Aptian, Albian stages of the Lower Cretaceous, the Cenomanian stage of the Upper Cretaceous, and the Neogene. Despite the registration of the placers, such as the Central (Cenomanian stage of the Upper Cretaceous), their development as independent minerals remains unprofitable. Therefore, there is the issue of the associated extraction of titanium and zirconium minerals during the extraction of building, glass, and moulding sand types. This issue was considered during the 1:200,000 additional site exploration works.

Methodology: The set tasks required the use of a variety of methods. Field studies, desk constructions of facial maps and sections, and laboratory and technological tests were carried out. Based on a comprehensive analysis of the data obtained, taxa for the regional mineragenic zoning were identified in the following ranks: mineragenic (ore) zones (OZ), regions (OR), and clusters (OC). During the performed work, core samples of more than 50 wells were documented and tested, rocks from over 100 observation points (outcrops and quarries) were described and tested within the Voronezh, Kursk, Lipetsk, and Oryol regions. Samples were prepared and the mineral and chemical composition of about 100 sand samples were studied using precision methods.

Results and discussion: Sand deposits of the Aptian stage with good potential to become a raw material for glass were examined for the content of heavy fraction minerals. The heavy fraction is represented by zircon, leucoxene, ilmenite association with small contents of disthene, rutile, staurolite, and tourmaline. The placers were formed due to rewashing and sizing of silt sand material in continental and coastal-marine environment. Multiple rewashing and sizing of sand is one of the main conditions for the accumulation of heavy fraction minerals. The titanium and zirconium placers are distant transport placers. The transport sources were for them were the more mature Paleozoic-Mesozoic sedimentary rocks of the Voronezh anteclise.

Conclusions: As a result of the 1:200,000 additional site exploration, for the first time, ore clusters were identified and registered, for which the predicted resources of the $\mathrm{P}_{3}$ category were calculated for titanium, zirconium, and glass sand.
\end{abstract}

Keywords: Sand, zircon-titanium raw material, 1:200,000 additional site exploration.

For citation: Kraynov A. V., Zvonarev A. E. New sources of titanium and zirconium minerals from the sand of the Aptian stage based on materials obtained during the 1:200,000 additional site exploration. Vestnik Voronezhskogo gosudarstvennogo universiteta. Seriya: Geologiya = Proceedings of Voronezh State University. Series: Geology. 2020, No.3, pp. 90-95. DOI: https://doi.org/10.17308/geology.2020.3/3012

The content is available under Creative Commons Attribution 4.0 License.

Alexey V. Kraynov, e-mail: aleksey_vsu_geo@mail.ru 
Conflict of interests: The authors declare the absence of obvious and potential conflicts of interest related to the publication of this article.

\section{REFERENCES}

1. Zvonarev A. E. O novom istochnike titan-tsirkonievogo syr'ya Tsentral'nogo Chernozem'ya [About a new source of titanium-zirconium raw materials from the Central Black Earth Region] // Kompleksnoe izuchenie $i$ osvoenie prirodnykh $i$ tekhnogennykh rossypei [Comprehensive study and development of natural and man-made placers], 2007, pp 42-3. (In Russ.)

2. Savko A. D., Mikhin V. P., Kholmovoi G. V. Lithology and useful minerals of the Aptian deposits jf the Don-Veduga-Devitza water-divide Trudy Nauchno-issledovatel'skogo Instituta Geologii [The work of the Research Institute of Geology], Voronezh, VSU Publ. vol. 26, 2004. 111 p. (In Russ.)

3. Savko A. D., Belyaev V. I., Ikonnikov N. N., Ivanov D. A. Titan-tsirkonievye rossypi Tsentral'no-chernozemnogo raiona [Titanium-zirconium placers of the Central Black Earth Region]. Voronezh, 1995. 148 p. (In Russ.)

4. Savko A. D. Istoricheskaya geologiya: uchebnoe posobie [Historical geology: study guide]. Voronezh, 2006, 450 p. (In Russ.)

5. Metallogenicheskii kodeks Rossii [Metallogenic code of Russia]. Moscow, Geokart-GEOS, 2012, 125 p. (In Russ.)
6. Krainov A. V., Manukovskii S. V. Mineragenic zoning of the ceramic clay, the Voronezh anteclise. Vestnik Voronezhskogo gosudarstvennogo universiteta. Seriya: Geologiya $=$ Proceedings of Voronezh State University. Series: Geology, 2020, no. 1, pp. 66-77 (In Russ.)

7. Savko A. D. Geologiya Voronezhskoj anteklizy. [Geology of the Voronezh anteclise]. Trudy Nauchno-issledovatel'skogo Instituta Geologii [The work of the Research Institute of Geology], Voronezh, VSU Publ. vol. 12, 2002. 165 p. (In Russ.)

8. Savko A. D. Manukovskij S. V., Mizin A. I., Burykin V. N., Bartenev V. K. Ob "yasnitel'naya zapiska k atlasu facial'nyh kart Voronezhskoj anteklizy. [Explanatory memorandum to the facies maps atlas of the Voronezh anteclise]. Trudy Nauchno-issledovatel'skogo Instituta Geologii [The work of the Research Institute of Geology], Voronezh, VSU Publ. vol. 20, 2004. 107 p. (In Russ.)

9. Krainov A. V., Goryushkin V. V. Mineral resources base of glass sands Central-Chernozem region and prospects for its growth. Vestnik Voronezhskogo gosudarstvennogo universiteta. Seriya: Geologiya $=$ Proceedings of Voronezh State University. Series: Geology, 2017, no. 1, pp. 90-95 (In Russ.).
Крайнов Алексей Владимирович - к. г.-м. н., доцент, Воронежский государственный университет, Воронеж, Российская Федерация; E-mail: aleksey_vsu_geo@mail.ru; ORCID 0000-0003-0038-0990

Звонарев Андрей Евгеньевич - к. г.-м. н., главный специалист, Обособленное структурное подразделение в городе Воронеже ООО «Медногорский медно-серный комбинат», Воронеж, Российская Федерация; E-mail: zvonandrej@yandex.ru; ORCID 0000-0002-5050-662X

Авторы прочитали и одобрили окончательный вариант рукописи.

\author{
Aleksey V. Kraynov - PhD in Geol-Min., Associate Professor, \\ Voronezh State University, Voronezh, Russian Federation; \\ E-mail: aleksey_vsu geo@mail.ru; \\ ORCID 0000-0003-0038-0990
}

Andrej E. Zvonarev - PhD in Geol-Min., Chief Specialist, Separate structural subdivision in the city of Voronezh LLC "Mednogorsk copper-sulfuric plant", Voronezh, Russian Federation; E-mail: zvonandrej@yandex.ru; ORCID 0000-0002-5050-662X

All authors have read and approved the final manuscript. 